\title{
A Need Analysis Approach In Developing Esp Module Based On Interactive Multimedia For Academy Industrial Technology Padang
}

\author{
Shally Amna ${ }^{1}$, Selfa Idriani ${ }^{2}$ \\ \{ shallyamna@upiyptk.ac.id ${ }^{1}$, selfaalana@gmail.com $\left.{ }^{2}\right\}$ \\ ${ }^{1}$ University of Putra Indonesia YPTK Padang, Indonesia \\ ${ }^{2}$ Bung Hatta University, Indonesia
}

\begin{abstract}
Need analysis is the first important step in developing ESP module. It is a way to gather information of needs towards the material, methods and strategy in teaching ESP. This research is aimed to find and analyze the need for developing ESP module for students in Agro-Industry department ATIP Padang using eight aspects of need analysis by Dudley-Evan and St. John (1998). The research is using descriptive qualitative approach. The object of the research is 81 students and 2 English lecturers. Data are collected by using questionnaires, interview and previous test result. Data are presented by using graph and description. The result shows that ESP module with most of out-ofclass activities is needed and the use of interactive multimedia in ESP class is recommended to be carried on. The result of this research will be used as matrix for the next research.
\end{abstract}

Keywords: need analysis, ESP, interactive multimedia.

\section{Introduction}

The need of having competency in speaking English this century has been inevitable. In order to step in to professional world, you must be able to communicate in international languages, including, English language. In realizing this fact, the government in Indonesia decrees that English must be used as one of the compulsory subjects taught in schools, colleges and universities.

The development of learning English in higher education in Indonesia has been set up as English as a foreign language. It is mostly classified into General English (GE) and English for Specific Purpose (ESP). General English is usually given as unspecifiable English language ability contain basic and general grammar and vocabulary, whereas English for Specific Purposes is given as a specific required English ability.

Learning English for specific purposes have been a good recommendation to be taught for non-English major students in the university. Besides having more technical vocabulary relate to the students' major, learning English for specific purpose also helps students to see their roles of study in global perspective. The students will read article, see videos, do activities which relate to their major in English which of course apply international standard. According to Hammer, ESP means "situations where the student has some specific reason to learn a language"[1]. In more specific idea, Hutchinson et al states ESP as " An approach to 
language teaching in which all decisions as to content and methods are based on learner's reason for learning.". The main characteristic of ESP is the orientation of the goals is more specific to the academic purposes or profession [2]. Furthermore, Dudley-Evan and St. John argue that ESP is a way of delivering materials and exercises which is appropriate to the students in a specific context[3].

Moreover, the content of ESP is designed and developed based on the concept of Need Analysis (NA). This concept is try to link the needs of students academically and professionally with the language courses given. In the other words, the English course gives more rooms for students to learn English which is related to their studies and job orientation in the future. In regards to the importance of NA, Richards explains that NA in teaching a language has some goals:

...to find out what language skills a learner needs; to help determine if an existing course adequately address the needs of potential students; to determine which students from a group are most in need of training in particular language skills; to identify a change of direction that people in reference group feel is important; to identify a gap between what students are able to $d$ and what they need to be able to do; and to collect information about a particular problem learners are experiencing.[4]

Based on the explanation, it is apparent that the urgency of carrying out Need Analysis in ESP in general is to find out to find the appropriate English learning methods, materials, tasks, activities, environment which is really needed by the students to be success in their study and their future career. Brown states that when all the needs have been identified, then they would become the goals of basis to develop suitable materials, exercises, tests, activities and evaluation strategy[5]. Knowing how important ESP for non-English department students, English lecturers try to do their best to provide the teaching materials. In Agro-Industry department of ATIP Padang, the materials and concepts of English course which has been taught tend to rely on the lecturers' decisions. Some lecturers, considering that the students only have one semester of learning English, may give more portion for GE. Some others think ESP would be better and try to collect and even to create materials which related to AgroIndustry subject from any resources. Yet, they are not always available. Some of the books and videos are provided online and published abroad. It also costs a fortune to purchase them, especially for the students.

In responding to the present situation, the research is done to find out the students' needs and wants from their English course in accordance with their major and job orientation. Since the needs of ESP for every students are different to their level of English skill, interest, and environmental support, it is very important to conduct Need Analysis (NA) towards the students' needs and wants. Overall, this research is aimed to gain information in the procedure of NA so the students can take English course based on their need and interests, to create a course which contains of English language which deals with Agro-Industrial aspects and finally to target that the results of the ESP course can be applied and used in the jobs the students will have in the future.

Based on the reasons, it is important to conduct the research of Need Analysis for ESP course, especially to the class in Agro-Industry department of ATIP Padang. The results of this research will also be used as a matrix of the next research, namely syllabus and material designs and development of ESP course in Agro-Industry department of ATIP Padang. 
The research of Need Analysis has been conducted by many researcher, notably, for those who wants to design and develop learning syllabus and materials for ESP courses. Hermawati has conducted a research of Need Analysis for Management Agro-Industry students in State Polytechnic of Jember [6]. Hilmi has also done Need Analysis of Flight Attendant Students in Learning English at LKP Graha Wisata Nusantara School, Padang[7]. They both used Need Analysis by using theory and concept by Hutchinson and Waters [8] which divided Target Needs and Learning Needs. The investigation done by Soroka about the way of reseraching ESP learners need has brought out some similar fact like how the lecturer and students in Ukranian universities acpect internet and textbook as two of their need in teaching and learning ESP [9]. The research of Hui also expose the need of teachers's skill to keep the students motivation and interesent in learning ESP [10]. Both of these implemented Need analysis by using varied questioners and interview. However, this research chose to use theory and concept proposed by Dudley-Evans and St. John [3] along with the article suggested by Wahyudi who developed English learning materials based on content-based approach for nursing students of STIKES Payung Negeri Pekan Baru [11]. Dudley-Evans and St. John divided Need Analysis into 8 aspects. The first aspect is wants, means, subjective analysis. It figures out the personal information of the students; the way they want to learn, etc. The second aspect is Present Situation Analysis. It requires information about the students' English competency and skill. The third aspect is Target Situation Analysis. It determines the activities and tasks which will be performed by students in English course. The fourth aspect is Lack Analysis. It finds out the students lacks - the gap between the ideal situation with the present situation in order to achieve the target of language learning. The fifth aspect is Learning Need Analysis. It is to find out the most effective way to learn English skills. The sixth aspect is Linguistics Analysis. This aspect determines the knowledge of how the language will be used in the target situation. The seventh aspect is What is wanted from the course. This aspects must have the students' needs and wants from the English course. And the last aspect is Means Analysis which gathers the analysis of information about 'the environment' where the course will be taken. In brief, the research is a Need Analysis research on students of Agro-Industrial department in ATIP Padang by using 8 aspects from DudleyEvans and St. John [3] which are partly questioned as follow:

1. How is the student need analysis of multimedia module based on the questioner given?

2. How is the lecturer need analysis based on the interview and previous test result?

\section{Methods}

The research is using qualitative descriptive approach. This is also a preliminary research of developing an ESP module with interactive multimedia as in the procedures of research and development method by Borg and Gall [12]. The object of the research were 81 students come from three classes of Agro-Industry department of ATIP Padang. The instrument of the research questioners designed by using 8 concept of Dudley-Evans and St. John [3], interview to the English lecturer and the previous test-result. The data were collected by using questioner which is given students in the academic year of 20018/2019 in Agro-Industry department of ATIP Padang. The questioner contained the questions derived from the elaboration the eight aspects proposed by Dudley-Evans and St. John The data from the questioners were analyzed by using simple statistics to find the mean of the results.

The steps of the research can be elucidated as follow:

1. Designing the questioners based on the eight concept of Dudley-Evans and St.John 
2. Giving the questioners to the respondents.

3. Collecting the questioners.

4. Analyze the data based on simple statistics.

5. Having the interview with the English lecturer.

6. Previewing the previous test-results of students from who have taken English course.

7. Presenting the result of the data collected descriptively.

Futhermore, the data of the reserach will reflect the need of students for ESP module and new method. The reseracher will use this data to develop new module and strategy in order to fulfill the needs and improve the students English capability in accordance with their diciplines.

\section{Result}

\subsection{Need analysis based on questioner's result}

In order to find out students need to develop a learning module of ESP with interactive Multimedia, the researchers have already given questioners to all students who learn English in Agro-Industry department, ATIP Padang. The questioner adapted eight aspects by DudleyEvans and St. John [3]. Some questions are customized in order to achieve the aims of the research.

\subsubsection{Wants, Means Subjective Analysis}

In the first aspect, students are given three questions. The questions are; (A1) how important English is to for the students, (A2) How often they do activities using English language, and (A3) What kind of English they want to learn in the only one semester to learn English. The students' answers of the questions are displayed in the bar diagram below. 


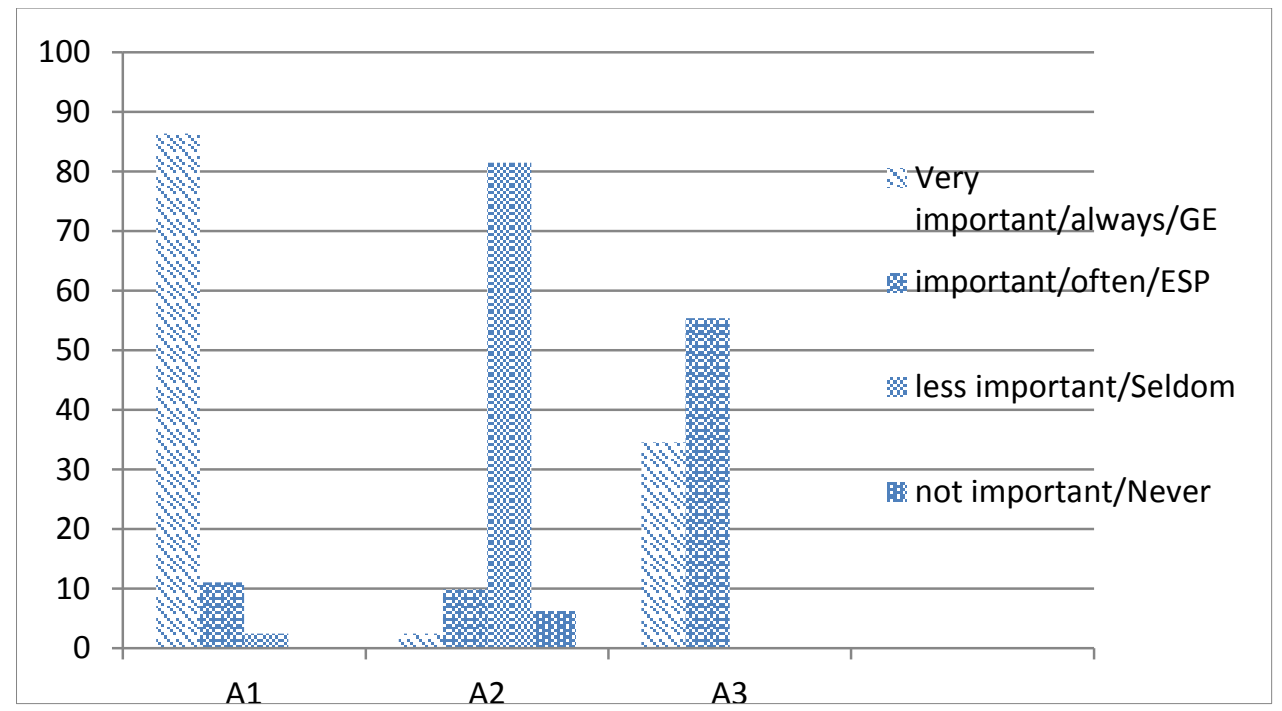

Figure 3.1 Wants, Means Subjective Analysis

The bar diagrams shows that the A1 got 86.4 percent for very important answer which means most students think that English is very important to learn. The A2 got 81.5 percent for seldom answer which indicates that most students seldom use English in their activities. And A3 got 65.4 percent for ESP which means most students believe that they should study English for specific purposes which relate to their major.

\subsubsection{Present Situation Analysis}

In the second aspect of NA, the questions asked about the present situation of the English class in the following context: (B4) whether the lecturer asked for the students need of English before began the class, (B5) whether the materials given had included the topics of their major (agro-industry), (B6) whether the material given had helped the students to comprehend more English for Agro-industry and (B7) whether English they learned had helped them to find work in Agro-industry field. The answer options are between yes and no. The answers of the questions are displayed below. 


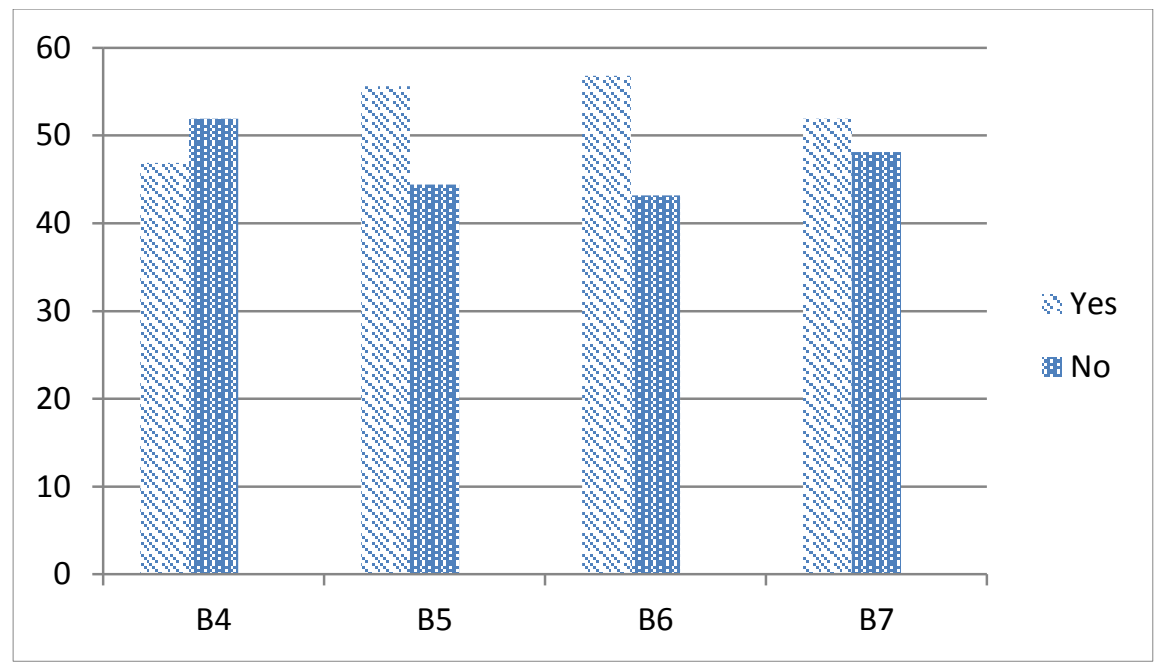

Figure 3.2 Present Situation Analysis

In figure 3.2, B4 bar hit 51.9 percent for no answer which means half and more students said that the lecturer did not try to find out their need before they began the class, and the rest students said yes. The questions in B5 bar hit 55.6 percent,, B6 hit 56.8 percent and B7 hit 51.9 percent for yes answers.

\subsubsection{Target Situation Analysis and Objective Needs}

The third aspect figured out the target situation of when they need ESP to work or to hunt jobs in agro-industry field. The students are required to mention which topics they think to be most important, important, less important and not-important to use when they work. The topics given are The Combine Harvest, Soils, Giving Instruction, Requesting, Ecological Problems, Irrigation, Water Pumping Systems, Agricultural Machinery and Tractor. Most students (about more than 60 percent) agreed that those topics would be very important when they work and also connected to their field of study.

\subsubsection{Lacks Analysis}

In the fourth aspect, the questions are given to find out the students ability in English in the scope of the six skills; (10A) listening, (10B) speaking, (10C) Reading, (10D) Writing, (10E) Vocabulary, (10F) Grammar. The rate focuses to discuss the students' lack ability in English. 


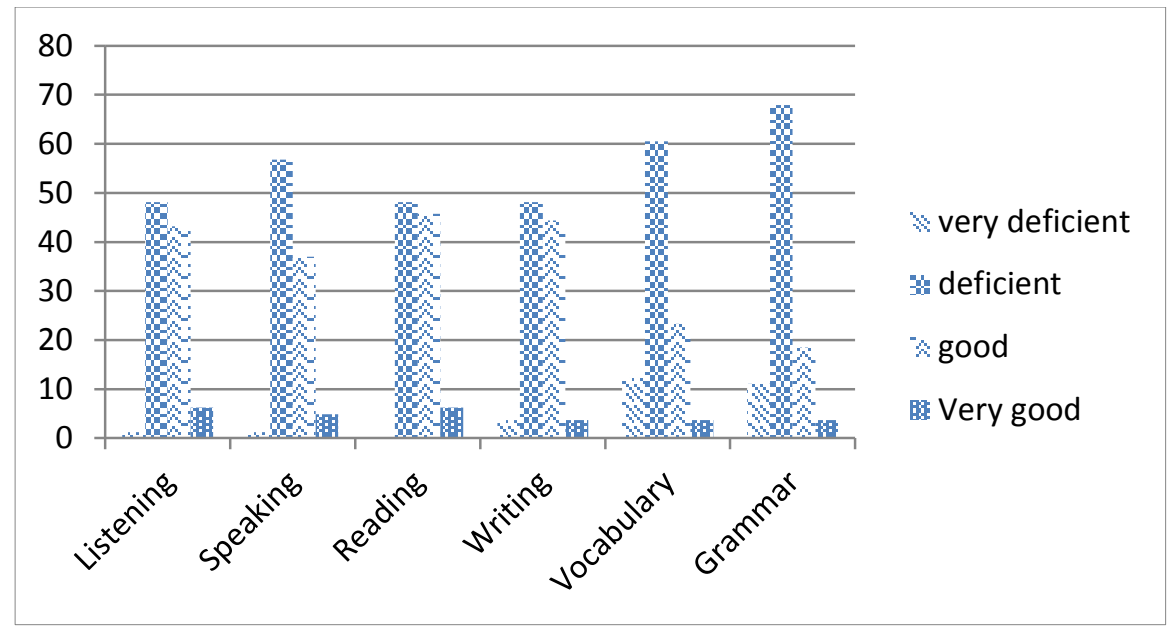

Figure 3.3 Lack Analysis

Figure 3.3 shows that most students faced lacks of competence in Grammar which shows in 67.9 percent for deficient answer and 11.1 for very deficient. The second lack is in vocabulary with 60.5 percent for deficient answer and 12.3 for very deficient. The third lack is in Speaking with 56.8 percent for deficient and 1.2 for very deficient. Question (11) asked how the students level of capability in using English in the purpose of agroindustry. The most percentage for this question is deficient, that is 72.8 percent.

\subsubsection{Learning Needs}

In learning needs aspect, the researcher analyzed the English skills that the students need to learn (E12) and the activities that the students want to do in English class (E13). In E12, the questions asked the students opinion about the skills that they need to learn in English class in order to master English in the field of agro-industry. The skills listed are listening, speaking, reading and writing. The results of the answers are shown as the bar diagram below. 


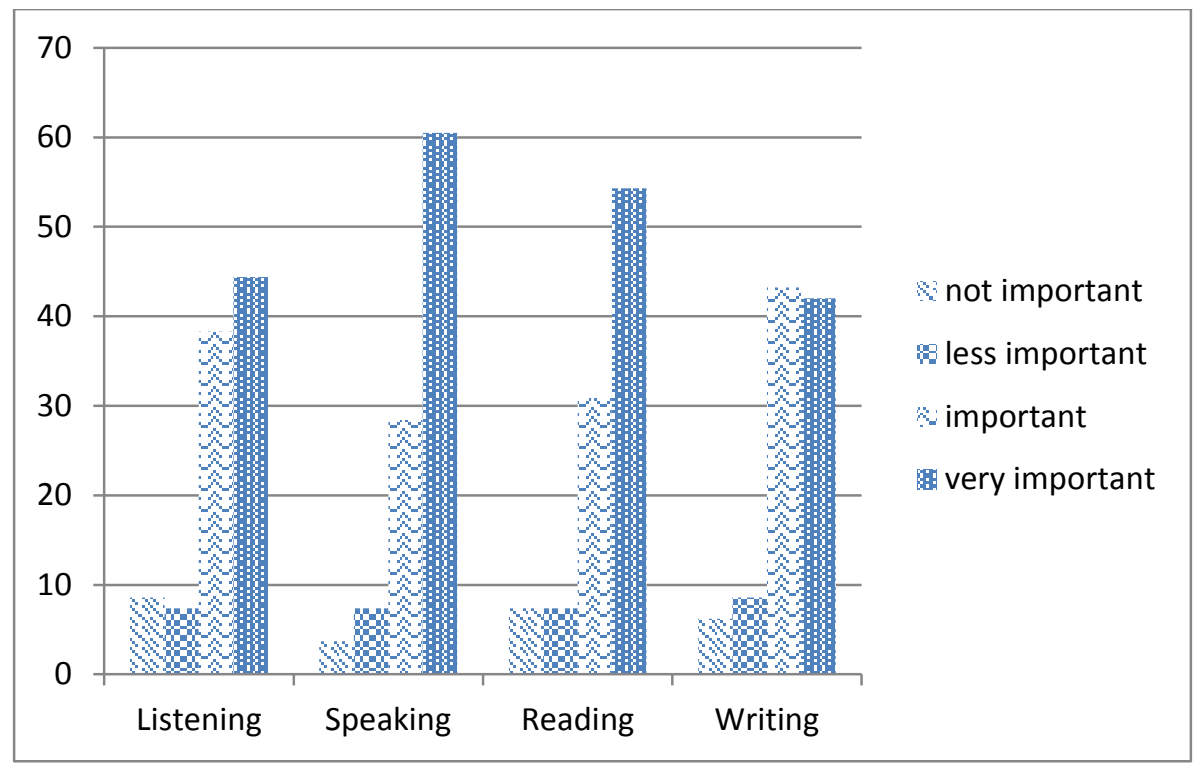

Figure 3.4 Learning Needs of English skills

In the figure 3.4, we can see that the most skill that the students think is very important to learn is Speaking with 60,5 percent for very important answer and Reading with 54,3 percent for very important answer. In E13 questions, the students are asked to decide which learning activities that they think important to support their progress in mastering English. The activities are specified into pair work, whole class, group work, out of class work, and individual. The students' answers are shown as the bar graph below.

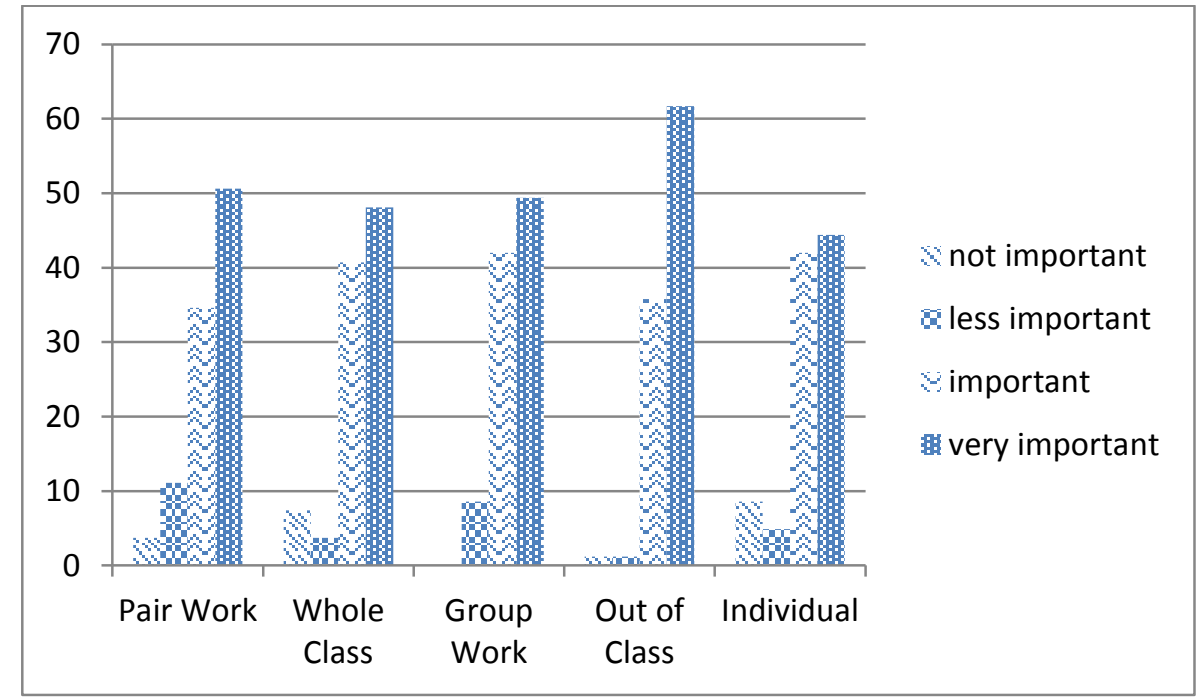

Figure 3.5 Learning Needs of English activities 
Based on the figure, it can be seen that the most needed English learning activity the students think is very important to perform in English class is out of class activity which hit 61.7 percent for very important answer. The second most important activity is pair work which hit 56.1 percent for very important answer. Other activities also were also considered very important although they gained less than 50 percent.

\subsubsection{Linguistics Analysis, Discourse Analysis, Genre Analysis}

In question (F14) the students were asked how often they found or read articles or other readings which contained agro-industry content and for about 56.8 students answered 'seldom'. In the question (F15) the students were asked to list some topics or ideas relate to agro-industry which need to be included as topics and materials in English class. The topics chosen by the students are Agricultural in general, tractor engineer, The Combine Harvest, Farm Management, Physical and Chemical Properties of Soil, Soil, Fertilization and Ecological Problems. Almost all of the students agree that the topics are considered important and very important to be discussed in English class.

\subsubsection{What is wanted from the Course}

The seventh aspect tried to find out the what the students hope to learn in enrolling English class. For about 84 percent answers said that they wanted to improve their English ability in the field of agro-industry and get the competency to get good job in the future.

\subsubsection{Means Analysis}

Question (17) asked about the educational background they student wanted the lecturer of English to have. Most of the students are expected to have English lecturer came from both English and Agro-Industry graduates. Question (18) asked the students perspective of ideal time to carry on English class during the academic years of Agro-Industry department, ATIP Padang. For about 60.5 percent answered that it is better to run the class in the second semester of the first year.

\subsection{Need analysis based on Interview with the lecturers and previous test result}

In order to gain the accurate need analysis of ESP module with interactive multimedia, the researcher also interviewed the lecturers who had already taught English in the previous years. The questions given are followed: (1) Do you have any module to teach English class?, (2) What kinds of materials given in class? Do they related to Agro-Industry field of study or ESP? (3) What are the sources of the material? (4) How are the students motivation in learning English? (5) How do you think the use of ESP module with interactive multimedia for students in department of Agro-Industry Padang?

During the year of 2017 and 2018, there are two lecturers taught English in three classes of Agro-Industry department ATIP Padang. Both of them are given interview separately and give the answers as follow: (1) Not yet. They did not have any module specifically for AgroIndustry students, they just used hand-outs during the meetings. (2) Most of the material given are reading which the topics given in ESP for Agro-Industry field. (3) The materials came from many sources like internet, Cambridge dictionary, etc. (4) The students have less motivation during the class activities but seems to be more excited in out-of-class activities. 
(5)The lecturers believe the use of ESP module with interactive multimedia will jack up the students motivation and competence ESP.

Besides having an interview, the researcher also asked the lecturers to show the students' previous test results. Unfortunately, only one lecturer who still kept the record of the score. The records shows that almost 60 percent students should have got $\mathrm{C}$ (deficient) for their English competence alone and only 10 percent got perfect score or A. However, considering both the hard work and the sedulity, there are only less than 50 percent students got grade under $\mathrm{C}$ (deficient) and more than 20 percent students got perfect score or A.

\section{Discussion}

After having the results of the questioners, the eight aspects of Need Analysis can be figured out. The first aspect reveals that the students already know the importance of studying English, though they seldom use it in most of their activities. This aspect also reveals that most students agree to learn ESP instead of GE. The main reason is because they only have one semester to study English during all the academic years in campus. Therefore, the researcher will develop English module based on the students need of disciplines. The second aspect reveals that shows that about fifty percent more or less students thought that they need had been represented in the English class they had already taken, and other fifty percent were still in doubt. As the matter of fact, the lecturers did asked them some questions and gave them material which related to certain topics of Agro-Industry, only that they did not always representative. Based on this situation, the researcher will continue to set a representative modules for Agro-industry.

In the third aspect, the students are required to think about the use of English in their disciplines. Some common topics related to Agro-Industry have been set and most students agreed that all of the topics are important to be mastered in English. All the topics will be the guidance and will be included when making the ESP module. The fourth aspects unveil the students lack in English competency. Since the most deficient skills are grammar, speaking and reading, the development of ESP module then will use more activities and exercises focusing to these skills.

The fifth aspect is discussing about the learning needs that is what and how the students want to learn English which they think might increase their English ability. The most skills chosen are speaking, reading and writing. The students also felt like they love to study out of class. Therefore, the main methods and strategy are proposed for the development of ESP module is the activities which are flexible and can be done anywhere and anytime like module with interactive multimedia. The sixth aspect also open up the students request of the English class to certain related topics. The seventh aspect is more technical. This brought out the students' demand of how English lecturer need to have knowledge in Agro-industry. This suggestion could be transferred to the stakeholders in the faculty.

Based on the interview and the previous test result, it reveals the fact that during the the lecturers have not designed any module for ESP class. So developing module for ESP class is considered urgent for now. Also, the lecturers said that the use of interactive multimedia in English learning seems promising and might bring positive improvement to the students ability in English. 


\section{Conclusion}

In developing a module, need analysis has become a vital procedure to follow. According to Otilia need analysis is "the foundation on which we can develop curriculum content, teaching materials and methods that can lead to increasing the learner's motivation and success" [13].

In carrying on need analysis for ESP, the researcher has adapted the aspects proposed by Evan - Dudley and St. John which contains aspects the students need from and after having ESP class technically and linguistically. By using this aspects, the researcher has set up the questioners to and asked students to answer. Besides that, need analysis may also include further information like interview with lecturers and stakeholders in the campus and also students' test result. What is gained in need analysis will then pursue to be the goals for designing the module, the methods and strategy in teaching.

The research of need analysis which has been done in department agro-industry ATIP Padang, has already gained information from the questioners, interview and test results. It can be concluded that the development of module for ESP is urgent especially in regards to some topics related to this discipline. Furthermore, the implementation of interactive multimedia is also considered as a breakthrough in engaging students to be active in English in and outside of the classroom.

\section{References}

[1] J. Hammer, The Practice of English Language Teaching. Longman, 1983.

[2] P. Robinson, An Overview of English for Specific Purposes. Oxford: Pergamon, 1989.

[3] T. and Duddley-Evans and M.J.St. John, Development in English for Specific Purposes Dudley Evan. Cambridge: CUP, 2009.

[4] J. . Richards, Curriculum Development in Language Teaching. Cambridge: Cambridge University Press., 2001.

[5] J. Brown, The Elements of Language Curriculum. New York: Heinle\&Heinle, 1995.

[6] D. A. Hermawati, "Analisis Kebutuhan untuk Pembelajaran ESP pada Kelas Managemen Agroindustri Politeknik Jember,” J. Ilm. Inovasi., vol. 15, no. 2, 2015.

[7] L. Hilmi, "Needs Analysis of Flight Attendant Students in Learning English at LKP Graha Wisata Nusantara School Padang," 2019.

[8] T. Hutchinson and Waters A, English for Specific Purposes: A Learning-Centred Approach. Cambridge: CUP, 1987.

[9] I. Soroka, "The Ways of Reserching ESP Learners' Needs as Seen by Teachers' of Ukrainian Universities," Adv. Educ., vol. 6, no. 11, pp. 4-9, Mar. 2019.

[10] GUO Hui, "The Learning Needs Analysis of English for Specific Purposes (ESP) in College," US-China Foreign Lang., vol. 15, no. 1, Jan. 2017.

[11] Wahyudi, "Developing English Learning Materials based on Content-Based Approach For Nursing Students of STIKES Payung Negeri Pekanbaru," 2016.

[12] W. R. Borg and M. D. Gall, Educational Research: An Introduction. New York: Longmen, 1989.

[13] S. Otilia, "Needs Analysis in English For Specific Purposes," Analele Univ. Constantin Brâncuşi din Târgu Jiu Ser. Econ., vol. 2, no. 1, pp. 54-55, 2015. 